\title{
Evaluation of chemical and physico-chemical indicators of water of the Resko lake on the basis of the European Union Water Framework Directive
}

\author{
Piotr Daniszewski ${ }^{1}$, Ryszard Konieczny ${ }^{2}$ \\ ${ }^{1}$ Department of Invertebrate Zoology and Limnology, University of Szczecin, \\ 13 Waska Street, 71-415 Szczecin, Poland \\ ${ }^{2}$ Institute of Technological and Life Sciences Falenty, Branch Poznań \\ 67 Biskupińska Street, 60-463 Poznań, Poland \\ E-mail address: daniszewski73@gmail.com
}

\begin{abstract}
The work shows the evaluation of physico-chemical parameters of water Resko lake, based on the European Union Water Framework Directive. Research was carried out in the years 2008-2009, in the period from April to October. With each of the three measuring stations on the tested water samples were taken two separate Lakes for chemical analysis. At the place of sampling were numbered $\mathrm{pH}$. Trying to test water were taken by Polish Standards. Collected water samples were fixed in accordance with the recommendations in the Polish Standards. Other indicators for the quality of the waters have been tagged within 24 hours from the moment of download attempts. Have studied lake close to neutral $\mathrm{pH}-7.63$ to 7.79. All lakes in accordance with the classification of the European Union Water Framework Directive have been included in the first class. Studies have shown a diverse water quality in lakes in relation to tested indicators. By analyzing the average annual values can be noted that the $\mathrm{pH}$ of the water, the $\mathrm{O}_{2 \text { diss }}$ and the concentration of $\mathrm{NO}_{3}{ }^{-}$showed a relatively small variation in all investigated Lakes. The level of the General Suspension in Resko lake the peasant was on level II class. The concentration in the surface layer of Ptot. Lake is little differentiated, is at level II quality class according to the classification of the European Union Water Framework Directive. The concentration of total phosphorus is $0,22-0,29 \mathrm{mg} \cdot \mathrm{dm}^{-3}$.
\end{abstract}

Keywords: water; lake; chemical and physico-chemical indicators; European Union Water Framework Directive

\section{INTRODUCTION}

Urbanization is the cause of many changes which is taking place in the environment, including those found in the catchment $[3-9,12,15,16,19,21,23,25]$. To address the increasing degradation of the surface waters in the European Union, changed the approach to the evaluation and protection of water resources. This approach was formulated in the European Union Water Framework Directive (2000/60/EC), which requires the protection of water and ecological and comprehensive approach to its assessment. Ecological status of surface water and groundwater is assessed on the basis of the ecological potential of the biological and physico-chemical and hydromorphological [5-10,12,14,18,23,24,27,29]. 
Implementation of the Water Framework Directive is to achieve good water status in all Member States of the European Union [3-6,8,11,13,15,18,24,26].

The work shows the evaluation of physico-chemical parameters of water Resko lake, based on the European Union Water Framework Directive.

\section{EXPERIMENTAL}

Lake Resko (Upper Resko) is located on the territory of Drawsko Lake District. The Resko lake is characterized by the following indicators of morphometric [22]:

- Latitude - N 53०40.7',

- Longitude - E $15^{\circ} 57.9^{\prime}$,

- the catchment area $-197,2 \mathrm{~km}^{2}$,

- the water catchment area - Rega,

- the surface of the water mirror is 50.7 hectares,

- height - 145,4 m above sea-level,

- the capacity of $1358,4 . \mathrm{m}^{3}$,

- the maximum depth - $5.0 \mathrm{~m}$,

- the average depth is $2,7 \mathrm{~m}$,

- maximum length $-1610 \mathrm{~m}$,

- maximum width - $1200 \mathrm{~m}$,

- the length of the shoreline $-7200 \mathrm{~m}$,

- development of the shoreline - 2.85,

- unveiling of the indicator - 18.8 .

Research was carried out in the years 2008-2009, in the period from April to October. With each of the three measuring stations on the tested water samples were taken two separate Lakes for chemical analysis. At the place of sampling were numbered $\mathrm{pH}$. Trying to test water were taken by Polish Standards. Collected water samples were fixed in accordance with the recommendations in the Polish Standards [7-12,14,16].

Other indicators for the quality of the waters have been tagged within 24 hours from the moment of download attempts. Determination of dissolved organic matter oxidation was vulnerable as COD-Mn in accordance with Polish Standards [7-12,14,16]. Dissolved oxygen has been marked in accordance with the methodology described by Winkler in the work of Daniszewski [7-12,14]. The degree of oxygenation of water specified by arrays in the work Nemerowa ${ }^{33}$. This work marked concentration of General Suspension, $\mathrm{BOD}_{5}, \mathrm{NH}_{4}^{+}, \mathrm{NO}_{2}^{-}$, $\mathrm{NO}_{3}{ }^{-}, \mathrm{PO}_{4}{ }^{3-}$ diss, $\mathrm{i}_{\mathrm{P}} \mathrm{Ptot}_{\text {- }}$ in accordance with the methodology described in the work of Daniszewski $[7-12,14,16]$. The quality objectives was evaluated according to the criteria recommended to evaluate inland surface waters as set out in the European Union Water Framework Directive (2000/60/EC) [18].

\section{RESULTS AND DISCUSSION}

The results of the Resko lake along with the classification in accordance with the European Union Water Framework Directive are presented in Table 1.

The $\mathrm{pH}$ of the water $\mathrm{pH}$ in Lakes influenced by physico-chemical and biotic interactions of environmental factors $[1,4,21,26,28,32]$. The degree of acidity affects directly the life 
processes occurring in ecosystems, among others. It is responsible for the correct download of nutrients by organisms. High alkalinity beneficial for assimilation, and the same use, located in water, nitrogen and phosphorus compounds are much more accessible than in an acid medium. Like high acidity, also clearly detrimental impact on organisms has excessive alkalinity of natural waters - $\mathrm{pH}$ above 9.0 [2,25-28,37].

Table 1. Results of the quality of surface water of Resko Lake (spring, summer and autumn 2008 - 2009) along with the classification values of indicators according to the criteria of the European Union Water Framework Directive (2000/60/EC)

\begin{tabular}{|c|c|c|c|c|c|}
\hline \multicolumn{6}{|c|}{ Resko Lake } \\
\hline \multicolumn{6}{|c|}{2008 year } \\
\hline No & $\begin{array}{c}\text { Water quality } \\
\text { indices }\end{array}$ & Units & $\begin{array}{l}\text { 19.04.2008 } \\
\text { Spring }\end{array}$ & $\begin{array}{l}\text { 26.07.2008 } \\
\text { Summer }\end{array}$ & $\begin{array}{c}17.10 .2008 \\
\text { Autumn }\end{array}$ \\
\hline 1. & $\begin{array}{c}\text { Total suspended } \\
\text { solids }\end{array}$ & $\mathrm{mg} \cdot \mathrm{dm}^{-3}$ & 18,9 (II) & 19,8 (II) & 20,2 (II) \\
\hline 2. & $\mathrm{pH}$ & - & 7,65 (I) & 7,63 (I) & 7,72 (I) \\
\hline 3. & COD-Mn & $\mathrm{mg} \mathrm{O}_{2} \cdot \mathrm{dm}^{-3}$ & 8,2 (III) & 8,7 (III) & 8,6 (III) \\
\hline 4. & $\mathrm{BOD}_{5}$ & $\mathrm{mg} \mathrm{O}_{2} \cdot \mathrm{dm}^{-3}$ & 3,9 (III) & 4,3 (III) & 4,6 (III) \\
\hline 5. & $\mathrm{O}_{2 \text { diss. }}$ & $\mathrm{mg} \mathrm{O}_{2} \cdot \mathrm{dm}^{-3}$ & 7,9 (I) & $7,3(\mathrm{I})$ & $7,5(\mathrm{I})$ \\
\hline 6. & $\mathrm{NO}_{3}^{-}$ & $\mathrm{mg} \mathrm{N} \cdot \mathrm{dm}^{-3}$ & $0,22(\mathrm{I})$ & $0,25(\mathrm{I})$ & $0,23(\mathrm{I})$ \\
\hline 7. & $\mathrm{NO}_{2}^{-}$ & $\mathrm{mg} \mathrm{N} \cdot \mathrm{dm}^{-3}$ & 0,032 (II) & 0,036 (II) & 0,033 (II) \\
\hline 8. & $\mathrm{NH}_{4}^{+}$ & $\mathrm{mg} \mathrm{N} \cdot \mathrm{dm}^{-3}$ & 1,21 (III) & 1,37 (III) & 1,18 (III) \\
\hline 9. & $\mathrm{PO}_{4}^{3-}$ diss. & $\mathrm{mg} \mathrm{PO}_{4} \cdot \mathrm{dm}^{-3}$ & 0,63 (III) & 0,79 (IV) & 0,62 (III) \\
\hline 10. & $\mathrm{P}_{\text {tot. }}$ & $\mathrm{mg} P \cdot \mathrm{dm}^{-3}$ & 0,24 (II) & 0,27 (II) & 0,25 (II) \\
\hline \multicolumn{6}{|c|}{2009 year } \\
\hline No & $\begin{array}{c}\text { Water quality } \\
\text { indices }\end{array}$ & Units & $\begin{array}{c}\text { 17.04.2009 } \\
\text { Spring }\end{array}$ & $\begin{array}{l}\text { 23.07.2009 } \\
\text { Summer }\end{array}$ & $\begin{array}{c}23.10 .2009 \\
\text { Autumn }\end{array}$ \\
\hline 1. & $\begin{array}{l}\text { Total suspended } \\
\text { solids }\end{array}$ & $\mathrm{mg} \cdot \mathrm{dm}^{-3}$ & 21,5 (II) & 24,7 (II) & 19,0 (II) \\
\hline 2. & $\mathrm{pH}$ & - & $7,68(\mathrm{I})$ & $7,79(\mathrm{I})$ & $7,71(\mathrm{I})$ \\
\hline 3. & COD-Mn & $\mathrm{mg} \mathrm{O}_{2} \cdot \mathrm{dm}^{-3}$ & 7,6 (III) & 8,2 (III) & 8,5 (III) \\
\hline 4. & $\mathrm{BOD}_{5}$ & $\mathrm{mg} \mathrm{O}_{2} \cdot \mathrm{dm}^{-3}$ & 4,4 (III) & 4,8 (III) & 4,2 (III) \\
\hline 5. & $\mathrm{O}_{2 \text { diss. }}$ & $\mathrm{mg} \mathrm{O}_{2} \cdot \mathrm{dm}^{-3}$ & $7,5(\mathrm{I})$ & $7,2(\mathrm{I})$ & $8,1(\mathrm{I})$ \\
\hline 6. & $\mathrm{NO}_{3}^{-}$ & $\mathrm{mg} \mathrm{N} \cdot \mathrm{dm}^{-3}$ & $0,37(\mathrm{I})$ & $0,39(\mathrm{I})$ & $0,38(\mathrm{I})$ \\
\hline 7. & $\mathrm{NO}_{2}^{-}$ & $\mathrm{mg} \mathrm{N} \cdot \mathrm{dm}^{-3}$ & 0,037 (II) & 0,039 (II) & 0,031 (II) \\
\hline 8. & $\mathrm{NH}_{4}^{+}$ & $\mathrm{mg} \mathrm{N} \cdot \mathrm{dm}^{-3}$ & 1,05 (III) & 1,26 (III) & 1,22 (III) \\
\hline 9. & $\mathrm{PO}_{4}^{3-}$ diss. & $\mathrm{mg} \mathrm{PO}_{4} \cdot \mathrm{dm}^{-3}$ & 0,67 (III) & 0,73 (IV) & $0,76(\mathrm{IV})$ \\
\hline 10. & $\mathrm{P}_{\text {tot. }}$ & $\mathrm{mg} \mathrm{P} \cdot \mathrm{dm}^{-3}$ & 0,22 (II) & 0,29 (II) & 0,26 (II) \\
\hline
\end{tabular}

Explanation: I, II, III, IV - classification of values of examined indicators in accordance with the European Union Water Framework Directive (2000/60/EC) 
Have studied lake close to neutral $\mathrm{pH}-7.63$ to 7.79. All lakes in accordance with the classification of the European Union Water Framework Directive have been included in the first class. In aquatic ecosystems of lakes have experienced loss of ignition loss and not the value of the COD-Mn according to estimates, which were made on the basis of the indications of "dry residues" and "residue after ignition" in accordance with the methodology set out by Macioszczyk [31] and on the basis of the results of COD-Mn, which always values match III class water quality-tested water lakes have shown continuing in all seasons of the year quite a significant content of organic substances, including substances of a gear. The cause of this condition should be found also in the bottom of the Lakes, which is at opulent fabric of organic [7,9,11-15]. The most important elements involved in primary production are phosphorus and nitrogen [24-26,35-38]. The presence of these substances determines the productivity of the water body, and the same for their quality. Biogen significantly affecting the quality of water included phosphorus [1,4,7-12,24-29].

This is the primary factor constraining the development of phytoplankton. And thus affect the massive algal blooms. This element occurs in the waters the form of inorganic phosphorus and dissolved organic forms [1,2,24,25,28,32,34-39]. The mineral phosphorus, phosphates are best absorbed by organisms, which play a huge role in primary production $[32,37,39]$. It is included in the circulation of matter, where content in the waters are not big get on minimum. So you should pay attention to phosphorus compounds in the demersal zone. The forms which occur and concentrated in the water depth of the Lake and are dependent from all types to use in catchment area. Nitrogen occurs in the form of gas dissolved in the water, ammonium ions, nitrate and nitrite. In Lakes is the main factor limiting the growth of organisms $[1,2,19,22,23,25,27,29,35,40,41]$.

Studies have shown a diverse water quality in lakes in relation to tested indicators. By analyzing the average annual values can be noted that the $\mathrm{pH}$ of the water, the $\mathrm{O}_{2 \text { diss }}$ and the concentration of $\mathrm{NO}_{3}{ }^{-}$showed a relatively small variation in all investigated Lakes.

The level of the General Suspension in Resko lake the peasant was on level II class. The concentration in the surface layer of $\mathrm{P}_{\text {tot }}$. Lakes is little differentiated, is at level II quality class according to the classification of the European Union Water Framework Directive. The concentration of total phosphorus is $0,22-0,29 \mathrm{mg} \cdot \mathrm{dm}^{-3}$. Tested water lakes were changing the concentration of the $\mathrm{PO}_{4}{ }^{3-}$ diss - these concentrations correspond to water quality from III to IV. The increase of the concentrations of phosphorus in the Lake may indicate a decrease in the amount of oxygen in the waters of the shallow and changes their status to release phosphorus compounds accumulated redox in sediment bottom [7,8,10,12-15,23,25]. In the case of nitrogen-compounds nitrates and nitrites values for these indicators were at level I and II class in all the surveyed lakes in accordance with the classification of the European Union Water Framework Directive.

Indicator, which indicates the high productivity of Lakes is the biochemical oxygen demand $\left(\mathrm{BOD}_{5}\right)$. The level of this indicator values on the studied Lakes was on level III class. In the remaining Lakes oxygen concentration was similar (continued in I class).

\section{CONCLUSION}

Have studied lake close to neutral $\mathrm{pH}-7.63$ to 7.79. All lakes in accordance with the classification of the European Union Water Framework Directive have been included in the first class. By analyzing the average annual values can be noted that the $\mathrm{pH}$ of the water, the $\mathrm{O}_{2 \text { diss }}$ and the concentration of $\mathrm{NO}_{3}{ }^{-}$showed a relatively small variation in all investigated Lakes. The level of the General Suspension in Resko lake the peasant was on level II class. 
The concentration in the surface layer of Ptot. Lake is little differentiated, is at level II quality class according to the classification of the European Union Water Framework Directive. The concentration of total phosphorus is $0,22-0,29 \mathrm{mg} \cdot \mathrm{dm}^{-3}$.

Tested water lakes were changing the concentration of the $\mathrm{PO}_{4}{ }^{3-}$ diss - these concentrations correspond to water quality from III to IV. In the case of nitrogen-compounds nitrates and nitrites values for these indicators were at level I and II class in all the surveyed lakes in accordance with the classification of the European Union Water Framework Directive.

Indicator, which indicates the high productivity of Lakes is the biochemical oxygen demand $\left(\mathrm{BOD}_{5}\right)$. The level of this indicator values on the studied Lakes was on level III class. In the remaining Lakes oxygen concentration was similar (continued in I class).

\section{References}

[1] Bajkiewicz-Grabowska E., J. Hydrol. Sci. 8 (1-2) (1981) 63-73.

[2] Bécares E., Limnetica 25(1-2) (2006) 143-154.

[3] Brzozowska R., Dunalska J., Zdanowski B., Limnol. Rev. 5 (2005) 11-16.

[4] Brzozowska R., Dunalska J., Zdanowski B., Arch. Pol. Fish. 15(4), (2007) 445-455.

[5] Brzozowska R., Gawrońska H., Limnol. Rev. 6, (2006) 39-46.

[6] Chudecki Z., Duda L., Pol. Soil Sci. 4(2) (1971) 145-154.

[7] Daniszewski P., International Letters of Chemistry, Physics and Astronomy 1 (2012) 6-12.

[8] Daniszewski P., International Letters of Chemistry, Physics and Astronomy 1 (2012) 13-16.

[9] Daniszewski P., International Letters of Chemistry, Physics and Astronomy 2 (2012) 42-45.

[10]Daniszewski P., International Letters of Chemistry, Physics and Astronomy 2 (2012) 46-52.

[11]Daniszewski P., International Letters of Chemistry, Physics and Astronomy 2 (2012) 35-41.

[12]Daniszewski P., The evolution of the geographical environment and nature protection in the industrialized and urbanized areas. 44 (2012) 16-21.

[13]Daniszewski P., Draszawka - Bołzan B., International Letters of Chemistry, Physics and Astronomy 4 (2012) 96-102.

[14] Daniszewski P., Draszawka - Bołzan B., International Letters of Chemistry, Physics and Astronomy 4 (2012) 103-111.

[15] Daniszewski P., International Letters of Chemistry, Physics and Astronomy 4 (2012) 112-118.

[16]Daniszewski P., International Letters of Chemistry, Physics and Astronomy 4 (2012) 119-124. 
[17]Daniszewski P., International Letters of Chemistry, Physics and Astronomy 5 (2012) $72-79$.

[18]DIRECTIVE 2000/60/EC of the European Parliament and of the Council of 23 October 2000 establishing a framework for Community action in the field of water policy. 2000. Off. J. Eur. Commun. L 327, 22 December.

[19]Dzienia S., Puzynski S., Wrzesinska E., Acta Agrophysica 16(1) (2010) 25-33.

[20]Fleituch T., Soszka H., Kudelska D., Kownacki A., Large Rivers vol. 13, Arch. Hydrobiol. Suppl. 141/3 No 3-4 (2002) 225-239.

[21] Garcia-Criado F., Tomé A., Vega F.J., Antolin C., Hydrobiologia, Kluwer Academic Publishers, Leon, 394 (1999) 209-217.

[22] Janczak J., Atlas Polish Lakes, 1996, 92-95.

[23] Kajak Z., Hydrobiology-limnology. Inland water ecosystems, PWN, Warsaw 1998, 355.

[24]Kajak Z., Ekol. Pol. 31 (1983) 495-530.

[25]Kalff J., Limnology. New Jersey 2001.

[26] Kownacki A., Soszka H., Guidelines for the evaluation of the status of rivers on the basis of macroinvertebrates and for intakes of macro-invertebrate samples in lakes, Warsaw 2004, 51.

[27]Kubiak J., Acta Sci. Pol. Piscaria 2 (1), (2003) 141-158.

[28]Kölling M., Meyniana 38 (1986) 1-19.

[29] Lampert W., Sommer U., Ecology of inland waters. Scientific Publishing PWN, Warsaw 2001, 415.

[30]Lelek A. Canadian Special Publication of Fisheries and Aquatic Sciences 106 (1989) 469-487.

[31] Macioszczyk A., Hydrochemistry, Ed. Geology, Warsaw, 1987, 475.

[32] Mudroch A., Azcue J. M., Mudroch P., (red) Influence of the use of a drainage basin on physical and chemical properties of bottom sediments of lakes, Lewis publishers

Boca Raton, New York, London, Tokyo 1997.

[33] Nemerow N. L., Stream, Lake, Estuary, and Ocean Pollution, Van Nostrand Reinhold Company, New York, 1985.

[34]Richards C., Host G. E., Arthur J. W., Freshwat. Biol. 29 (1993) 285-294.

[35] Trojanowski J., Antonowicz J., Król M., Bruski J., Annales of the Polish Chem. Soc. 1 (2001) 131-138.

[36] Trojanowski J., Bruski J., Baltic Coastal Zone 4 (2000) 53-66.

[37] Van Urk G., de Vaate B., Limnologie Aktuell 1 (1990) 131-145.

[38] Vollenweider R. A. Scientific fundamentals of the eutrophication of lakes and flowing waters, with particular reference to nitrogen and phosphorus as factors in eutrophication. DAS/CSIO/68.27, OECD, Paris, 1968, 192. 
[39] Wright J. F., Moss D., Armitage P. D., Furse M. T., Freshwat. Biol. 14 (1984) 221-256.

[40]Zdanowski B., Ekol. Pol. 31 (1983) 287-308.

[41]Zdanowski B., Ekol. Pol. 31 (1983) 333-352. 